Type: Article Research

\title{
METODE CULTURAL RESPONSIVE TEACHING DALAM PENDIDIKAN AGAMA ISLAM: STUDI KASUS TINDAK XENOPHOBIA DAN RASISME DI TENGAH BENCANA COVID-19
}

\author{
Mansurni Abadi ${ }^{1}$ dan Nafik Muthohirin ${ }^{2}$ \\ Universitas Kebangsaan Malaysia' ${ }^{1}$, Universitas Muhammadiyah Malang ${ }^{2}$ \\ Email: abadimansur25@gmail.com; nafikmuthohirin@umm.ac.id
}

\begin{abstract}
Abstrak
Artikel ini ingin menjelaskan pendekatan Cultural Responsive Teaching (CRT) dalam pembelajaran Agama Islam sebagai upaya mengatasi peningkatan tindak xenophobia dan rasisme di tengah merebaknya Covid-19. Metode penggalian data dilakukan berdasarkan kajian pustaka yang bersumber dari buku, jurnal, media massa dan berbagai ungkapan bernada rasisme dan xenophobia yang mengemuka di beranda Facebook, Twitter, grup-grup WhatsApp dan akun media sosial lainnya. Naskah ini akan menjelaskan beberapa hal penting, di antaranya mengenai CRT sebagai sebuah pendekatan melihat keberagaman budaya, etnis, agama dan kelompok; titik temu pendekatan CRT implementasi pembelajaran agama Islam, dan elaborasi di antara keduanya dalam menyuarakan pentingnya menghindari narasi-narasi berdasarkan rasisme dan xenophobia.
\end{abstract}

Kata Kunci: Cultural Responsive Teaching, Pendidikan Agama Islam, Rasisme, dan Xenophobia.

\begin{abstract}
This article would like to explain the Cultural Responsive Teaching (CRT) approach in the learning of Islamic religion as an alternative effort to overcome the increase in xenophobia and racism action in the midst of the Covid-19. The method of extracting data is based on a literature review sourced from books, journals, mass media and various expressions of racism and xenophobia that emerge on the homepage of Facebook, Twitter, Whats App groups and other social media accounts. This paper will explain several important things, including CRT as an approach to see the diversity of cultures, ethnicities, religions and groups; the meeting point of the CRT approach to the implementation of Islamic religious learning, and the elaboration between the two in voicing the importance of avoiding narratives based on racism and xenophobia.
\end{abstract}


Key Words: Cultural Responsive Teaching, Islamic Religious Education, Racism, and Xenophobia.

\section{Pendahuluan}

Coronavirus Disease 2019, atau biasa disebut Covid-19, menciptakan ketakutan kepada khalayak luas. Hingga artikel ini ditulis, pandemi ini tengah menginfeksi lebih dari 7 juta jiwa dan mengambil lebih dari 409 ribu nyawa manusia secara global. ${ }^{1}$ Penularan wabah ini terbilang cepat hingga memunculkan rasa takut berlebih bagi masyarakat. Secara psikologis, ketakutan berlebih yang terjadi nyatanya dimanfaatkan pihak tertentu untuk membangkitkan diskriminiasi, kekerasan, dan intimidasi dalam bentuknya yang paling umum berupa xenophobia (ketakutan terhadap orang asing secara berlebihan) dan dalam bentuknya yang paling spesifik berupa rasisme (diskriminasi yang sistematis terhadap golongan tertentu yang dianggap sebagai sumber virus).

Kemunculan sentiman ras dan ketakutan berlebih terhadap orang asing ketika terjadi bencana sejujurnya telah diprediksi Ariely (2016). Sebagai bagian dari serangkaian tindakan rasional akibat keterancaman, terutama ketika terjadi krisis di tengah masyarakat, maka rasisme dan xenophobia sangat mungkin akan muncul secara tidak sadar. ${ }^{2}$ Jadi, jika Covid-19 dianggap sebagai virus yang membahayakan seseorang dengan imunitas yang rendah, maka rasisme dan xenophobia telah menjadi "virus" bawaan yang membajak situasi pandemi seperti situasi saat ini. Dampak rasisme dan xenophobia juga tak kalah "menyakitkan" karena mampu merobek harmoni sosial.

Kemunculan tindak rasisme dan xenophobia di tengah sebuah bencana, sesungguhnya bukan pertama kali ini. Peristiwa yang seperti ini terjadi secara berulang di beberapa kasus merebaknya pandemi secara global. Ketika wabah SARS menyerang kawasan Asia pada 2003, sentimen yang tak jauh berbeda juga menimpa. Jenn Fang dalam artikelnya yang diterbitkan Washingtonpost (4/2/2020) bertajuk SARS Outbreak Fueled Anti Asian Racism: This Pandemic Doesn't Have To, menceritakan bagaimana kepanikan ras menyelimuti warga Toronto dengan memboikot dagangan yang dimiliki warga keturunan Kanada-Asia di Pacific Mall, sebuah pusat perbelanjaan yang didominasi penduduk Asia di Amerika Utara. Aksi boikot warga lokal tersebut membuat usaha-

\footnotetext{
1 Angka persisnya mencapai 7,231,354 dan menjangkiti sebanyak 215 negara di dunia sejak artikel ini dikutip dari https://www.worldometers.info/coronavirus/ pada Rabu, 9 Juni 2020. Jumlah kasus orang yang terinfeksi ini kemungkinan dapat terus bertambah karena hingga artikel ini ditulis, setiap hari ribuan orang dinyatakan positif terinfeksi Covid-19.
}

2 Dan Ariely. Predictably Irrational: The Hidden Forces that Shape our Decisions (New York: Pinguin, 2016). 
usaha warga beretnis Asia lebih dari 80 persen tutup. ${ }^{3}$ Begitupun ketika wabah Ebola terjadi pada 2014 di Afrika. ${ }^{4}$

Hanya saja, terdapat perbedaan intensitas antara tindak rasisme dan xenophobia yang terjadi pada pandemi sebelumnya dengan yang sekarang. Saat ini, sentimen rasisme dan xenophobia bertemu dengan kecanggihan teknologi, sehingga secara kuantitas aksi kebencian terhadap ras tertentu dan ketakutan terhadap warga asing lebih luas, tidak hanya memenuhi interaksi di dunia nyata melainkan juga komunikasi di dunia maya. Sentimen tersebut meluas dalam bentuknya yang baru, yang tidak dijumpai pada saat terjadinya pandemi SARS atau Ebola, yaitu berupa berita bohong (hoax) yang berbentuk narasi pendek, gambar/meme, bahkan video pendek bernadakan provokasi terhadap etnis atau orang asing tertentu.

Kecurigaan dan kebencian yang seperti ini justru tidak menjadikan warga menjadi "sehat", tetapi justru membuat penyakit sosial yang tingkat kesembuhannya justru lebih sulit didapat. Kabar bohong berbasiskan rasisme dan xenophobia hanya melahirkan tindak kekerasan dan diskriminasi yang sangat mungkin terjadi di dunia nyata dalam bentuknya persekusi dan main hakim sendiri (jika terjadi di media sosial disebut digital vigilantism). Tampaknya, yang disebut terakhir tersebut, yang menjadi kekhawatiran global hingga Direktur Jenderal WHO (World Health Organization) Antonio Gutterez menegaskan agar masyarakat waspada terhadap berita bohong tentang Covid-19 dan isu yang membangkitkan rasisme. Berbagai narasi bohong di media sosial tersebut hanya bertujuan menebar rasa takut dan kepanikan berlebih.

Tetapi, fenomena yang demikian tidak cukup dipandang sebagai ekspresi reaksioner masyarakat semata. Fakta yang berada di balik merebaknya rasisme dan xenophobia di tengah pandemic harus dilihat secara lebih kritis bahwa ada upaya yang sistematis dari kelompok kepentingan tertentu yang memanfaatkan situasi darurat seperti sekarang untuk menyesatkan pola berpikir masyarakat sehingga menjadikan situasi sosial, ekonomi, politik dan ketahanan sebuah negara menjadi rapuh.

Pada kasus sentimen anti-China, misalnya, penularan Covid-19 hanyalah pemantik dari meledaknya sentimen kepada warga atau keturunan negeri berpenduduk satu milyar lebih tersebut. Sentimen terhadap China sesungguhnya dibangun sejak lama oleh musuh-musuhnya, ditambah lagi dengan rekam sejarah yang penuh tensi antara masyarakat lokal dengan warga keturunan China di manapun mereka berada. Kondisi

\footnotetext{
${ }^{3}$ Baca selengkapnya dalam artikel Jenn Fang. "SARS Outbreak Fueled Anti Asian Racism. This Pandemic Doesn't Have To" (Washingtonpost, 4/2/2020).

4 Baca selengkapnya dalam artikel Anthony Curcer. "Crying 'Racisme' on Ebola" (National Review, 20/10/2014).
} 
demikian juga diperparah dengan pembingkaian (framing) media yang memberitakan persebaran Covid-19 dari negeri tersebut. Perpaduan antara pembingkaian media, tensi sejarah dan pengaruh geopolitik ini yang menyebabkan gelombang rasisme dan xenophobia terhadap etnis China meningkat.

Kenyataannya, rasisme dan xenophobia tidak hanya menimpa etnis China, tetapi juga etnis dan kelompok lainnya, terutama warga imigran baik yang datang sebagai pengungsi ataupun pekerja ke suatu negara tertentu. Kasus di Malaysia, bahkan melibatkan sentiment agama dengan memviralkan berbagai narasi anti agama tertentu karena kluster Covid-19 di Malaysia juga terdeteksi dari pertemuan keagamaan yang melibatkan jamaah Tabligh di Malaysia dan Indonesia, jemaah geraja di Korea, dan pemeluk Yahudi Orthodox di Israel. Tiindakan rasisme dan xenophobia mengalami peningkatan yang terjadi pada imigran Rohingya, Bangladesh, dan Indonesia. Berawal dari isu pekerja asing tanpa izin, lalu mereka dianggap tidak mematuhi perintah kawalan pergerakan.

Tentu saja, tidak semua masyarakat Malaysia membenarkan rasisme dan xenophobia yang biasanya lebih banyak disuarakan di media sosial ini. Berbagai kampanye untuk melawan balik segala bentuk framing yang mengarah pada kedua penyakit sosial juga masif dilakukan warga Malaysia, salah satunya kampanye on line dengan hastag \#imigranjugamanusia.

Kejadian serupa juga terjadi di Singapura terhadap para pekerja imigran, terutama dari India dan Bangladesh, yang oleh sebagian pihak yang mengampanyekan rasisme dan xenophobia disebut sebagai manusia dari negara terbelakang yang terbiasa hidup kotor. Artikel Balli Kaur Jaswal berjudul Rise Coronavirus Cases Brings Light Singaporians Racist Attitude, yang terbit di South China Morning Post (23/4/2020), membuktikan kebenaran akan merebaknya tindak xenophobia yang dilakukan warga lokal terhadap tenaga kerja asing. Menurutnya, banyak artikel hoax yang berisikan tentang tuduhan kepada imigran sebagai awal pembawa virus di negara mereka. Salah satu isi pesan berantai yang viral dan memuat bentuk xenophobia, yaitu:

"Ada sebanyak 20 ribu pekerja asing yang sedang dikarantina di beberapa asrama besar saat ini. Jika 2 persen saja yang terinfeksi, mereka akan menginfeksi pacar pembantu mereka secara terusmenerus. (Mengenai hal ini), kami telah mewawancarai sebanyak 400 rumah tangga yang telah terinfeksi." 5

\footnotetext{
${ }^{5}$ Baca selengkapnya dalam Balli Kaur Jaswal. "Rise Coronavirus Cases Brings Light Singaporean Racist Attitudes", South China Morning Post (23/4/2020).
} 
Berbeda dari Malaysia, hampir sebagian besar imigran yang tinggal di dormitori yang padat ${ }^{6}$ memang menjadi kluster terbesar yang terinfeksi Covid-19 di Singapura. Problem ini mendorong negara tersebut untuk melakukan lockdown yang mereka sebut circuit breakers sejak 3 April 2020, dan berakhir pada 2 Juni 2020.

Bahkan, tindak rasisme yang terjadi di Thailand menimpa turis asal Eropa -Farrang sebutan lokalnya. Ironisnya, pernyataan bernada rasisme dan xenophobia tersebut lahir dari ucapan Menteri Kesehatan Thailand Anutin Charnvirakul. Sebagaimana dikutip dari artikel Richard S Ehrilch, Anutin menganggap turis kulit putih sebagai manusia kotor yang menyebabkan warga Thailand terinfeksi Covid-19.7

\section{Implementasi dalam Pembelajaran Islam}

Menurut hemat penulis, himbauan dan ancaman hukuman tidak cukup menghentikan segala tindak xenophobia dan rasisme, baik yang kerap terjadi saat pandemi maupun dalam kondisi normal. Namun, saat bencana Covid-19 menyerang dan seluruh negara tengah mencari jalan keluar dari situasi darurat ini, interaksi sosial jangan diperperah dengan memunculkan rasisme dan xenophobia. Sebab, dengan menunjuk kesalahan orang lain berdasarkan ras, hal ini menunjukkan watak sipil yang diskriminatif dan anti hak asasi manusia. Penanganan terhadap konstruksi sosial berbasiskan rasisme dan xenophobia tersebut akan sulit ditangani dibanding mengatasi persebaran Covid-19.

Sebab itu, salah satu jalan keluar yang penting dan sistematis dalam mengupayakan terhapusnya bentuk rasisme dan xenophobia di masyarakat, adalah melalui strategi pendidikan, khususnya Pendidikan Agama Islam. Dalam proses pembelajaran Agama Islam perlu bertitik tekan pada internalisasi, aktualitasi, dan implementasi nilai-nilai kemanusiaan yang didasarkan pada nilai-nilai Al-Qur'an. Hal ini relevan untuk membaca kasus, misalnya di Indonesia, dan belakangan banyak terjadi tindak persekusi dan narasi kebencian berbasiskan SARA di media sosial. ${ }^{8}$

Namun, model intrepretasi terhadap teks Al-Qur'an haruslah berorientasi pada progresivitas dan keterbukaan pandangan sebagaimana yang dicontohkan Farid Esack, Kuntowijoyo, Asghar Ali Engineer, Jasser Auda, Mashood A. Baderin, Abdullah An-

7 Dikutip dari Richard S Ehrilch. "Thailand Blames its Covid-19 Crisis on Caucasians", Asia Times.com (20/3/2020).

8 Untuk melihat fenomena persekusi dan narasi kebencian berbasiskan sentimen ras, agama dan golongan yang menghadirkan pendidikan Islam sebagai jalan dialognya, baca dalam Nafik Muthohirin. "Politik Identitas Islam dan Urgensi Pendidikan Multikultural." Jurnal Pendidikan Agama Islam (J-PAI) UIN Maulana Malik Ibrahim Malang, Vol. 6 No. 1 Juli-Desember 2019. 
Naim, Fazlur Rahman dan ilmuwan muslim progresif lainnya. Farid Esack, misalnya, menggunakan ayat-ayat bermuatan pluralism untuk melawan rezim apartheid dengan tesisnya yang terkenal "teologi pembebasan Islam". Menurutnya, teologi pembebasan Islam berarti sebuah upaya untuk melakukan kontekstualisasi ayat-ayat Al-Qur'an terhadap berbagai permasalahan sosial yang muncul. Juga, sesuatu yang bekerja ke arah pembebasan agama dari struktur serta ide sosial, politik, dan religius yang didasarkan pada ketundukan yang tidak kritis dan pembebasan seluruh masyarakat dari semua bentuk ketidakadilan dan eksploitasi ras, gender, kelas dan agama. ${ }^{9}$

Begitu pentingnya kepedulian sosial bagi masyarakat yang beragama, hingga Farid Esack menegaskan:

"Islam as a religion is also a way of life and the ritual forms of worship are a part of religion; they are an important part, but still only a part. If our worship is not linked to our lives and to people's suffering, then it becomes a safe part of religion, a part that all the decision makers in unjust socioeconomic structures would want to encourage. The separation between this-worldly and otherworldly matters has never really struck a responsive chord in the world of Islam". 10

Pernyataan Esack tersebut sangat tegas memposisikan masyarakat beragama supaya memiliki empati terhadap penderitaan orang lain, bukan malah menghakimi orang lain karena faktor kemajemukan. Dalam hal ini, agama sebagai pedoman dalam bersikap, memupuk nilai-nilai, dan panduan hidup seseorang, penting berperan dalam meminimalisir terjadinya tindakan rasisme dan xenophobia. Apalagi untuk wilayah Nusantara yang multikultural seperti Indonesia dan sejumlah negara di Asia Tenggara lainnya, pendidikan agama perlu diorientasikan pada penyelesaian problem-problem sosial. Hal ini karena memandang bahwa setiap agama mengajarkan nilai universal, yaitu penghargaaan terhadap orang lain.

Sebagai salah satu agama terbesar di dunia, Islam merupakan agama mayoritas yang dianut masyarakat nusantara, yang mencakup Indonesia, Brunei Darussalam, Singapura, Thailand bagian selatan, dan Filipina bagian selatan. Sebab itu, pendidikan Islam yang berorientasi pada penyemaian ide-ide "teologi pembebasan Islam" atau "Islam profetik" perlu diaktulisasikan secara menyeluruh di berbagai tingkat lembaga pendidikan. Hal ini karena rasisme dan xenophobia adalah perilaku munkar terhadap sesama manusia. Allah Swt menciptakan manusia sebagai makhluk yang mulia, sehingga jika manusia yang menzhalimi manusia yang lain, niscaya mereka akan mendapatkan balasan yang setimpal. ${ }^{11}$

\footnotetext{
${ }^{9}$ Lihat dalam Farid Esack. Qur'an, Liberation E Pluralism: An Islamic Perspective of Interreligious Solidarity Againts Oppression, lihat terj. Al-Qur'an, Liberalisme, Pluralisme: Membebaskan yang Tertindas (Bandung, Mizan: 2000), 120.

${ }^{10}$ Farid Essack. On Being A Muslim: Finding a Religious Path in the World Today (London: Oneworld Publication, 2009).

${ }^{11}$ Baca Q.S. Al-Isra': 70.
} 
Bahkan, jika membaca ulang sejarah, para pengikut awal Nabi Muhammad Saw berasal dari kalangan mustad'afin, orang miskin dan budak yang tertindas dan terdiskriminasi, misalnya saja Bilal bin Rabah dan Ammar bin Yasir. Al-Qur'an juga mengajarkan, tidak ada yang membedakan antara ras, warna kulit, dan identitas primordial lainnya antara satu dengan yang lainnya. Semuanya sama dan setara di hadapan Allah Swt. ${ }^{12}$ Ayat ini sering dikutip para mubaligh sebagai argumentasi bahwa tidak ada yang perlu diistimewakan dari seseorang, apalagi karena harta atau rupanya, melainkan hanya takwa kepada Allah Swt.

Farid Esack kembali menegaskan dengan menyontohkan pengalamannya melawan rezim otoritarian apartheid di negaranya. Ketakwaan seseorang adalah kunci bagi perjuangan menegakkan Islam progresif dan anti-diskriminasi. ${ }^{13}$ Menurutnya, Islam pada dasarnya sangat progresif dan revolusioner dalam usahanya membuat dunia menjadi lebih baik. Baginya, ketika Al-Quran menggunakan diksi takwa, berarti pemaknaannya tidak hanya terbatas pada ritual semata, tetapi memiliki semangat revolusioner dan progresif. Karena itu, takwa selalu berkaitan dengan keimanan dan interaksi sosial.

Doktrin Islam yang menginspirasi pemikiran dan gerakan revolusioner tersebut dapat dicontohkan dalam beberapa hal berikut, seperti, berbagi kepada orang lain, ${ }^{14}$ menepati janji, ${ }^{15}$ dan terutama berbuat baik kepada orang lain, ${ }^{16}$ dan menolong orang miskin. ${ }^{17}$ Tesis ini juga sejalan dengan prinsip universal Islam yang pertama kali diperkenalkan Imam Abu Hamid al-Ghozali sebagai al-Kulliyatu al-Khoms, yakni: Hifdzu al-Aql (menjaga akal); Hifdzu al Din (menjaga agama); Hifdzu al-Mal (menjaga harta); dan Hifzu al-'Ird wa al-Nasl (menjaga harga diri dan keturunan). ${ }^{18}$ Kemudian, ajaran Nabi Muhammad Saw jelas menolak segala bentuk diskriminasi, termasuk diskriminasi atas dasar ras, kelompok, bahkan dalam hal keyakinan beragama.

Islam dengan semangat pembebasan, kesetaraan, dan keadilannya yang diajarkan dalam Al-Quran dan diteladankan Nabi Muhammad tersebut bisa berpengaruh pada

\footnotetext{
${ }^{12}$ Lihat dalam Q.S. Al-Hujurat: 13.

${ }^{13}$ Farid Esack. Qur'an, Liberation and Pluralism: An Islamic Perspective of Interreligious Solidarity against Oppression. (London: Oneworld Publication, 1997).

${ }^{14}$ Baca Q.S. Al-Lail: 5.

${ }^{15}$ Baca Q.S. Ali-Imran: 76

${ }^{16}$ Baca Q.S. Ali-Imran: 172

${ }^{17}$ Baca Q.S. Al-Maun: 1-7

${ }^{18}$ Maka jika kembali pada Surat al-Hujurat ayat 13, hal ini juga berkorelasi dengan sabda Rasulullah Saw yang tercantun dalam Sahih Muslim yang artinya: "Sesungguhnya Allah tidak melihat badan dan rupa kalian, melainkan Dia melihat hati kalian."
}

Mansurni Abadi dan Nafik Muthohirin. Metode Cultural Responsive Teaching dalam Pendidikan Agama Islam.....pp: $34-48$ 
setiap situasi genting, sebagaimana saat ini di mana Covid-19 mengancam peradaban manusia secara global. Namun, untuk mencapai hal ini, Islam perlu dipahami tidak hanya secara literal saja, tetapi juga secara rasional sehingga pemahaman dan penerapannya bisa sesuai dengan nilai-nilai keadilan dalam upayanya merespons xenophobia dan rasisme.

Dalam hal ini, pendidikan menjadi aspek kunci karena pendidikan agama Islam adalah proses penting yang melibatkan serangkaian organisasi dan implementasi berdasarkan aspirasi, niat dan motivasi untuk menerjemahkan ajaran dan nilai-nilai Islam melalui kegiatan pendidikan. Hasil akhirnya, ini mampu menciptakan generasi yang berakhlakul karimah.

Tetapi untuk mencapai semua itu butuh berbagai jenis pendekatan yang tepat yang salah satunya harus responsif terhadap keberagaman. Karena itu, implementasi pendidikan agama Islam perlu elaborasi dengan Cultural Responsive Teaching (CRT) sebagai metode pendidikan yang cocok dalam konteks multikulturalisme untuk merespons segala bentuk keterjebakan saat ini yang berbentuk rasisme dan xenophobia. Elaborasi Pendidikan Agama Islam dengan CRT ini bisa menjadi gerakan alternatif melawan segala bentuk tindak xenophobia dan rasisme.

\section{Titik Temu}

Lardson-Billing menyebut CRT sebagai pendekatan pembelajaran yang responsif terhadap keanekaragaman budaya dari pentingnya pengalaman setiap peserta didik. ${ }^{19}$ Pendekatan ini mampu diperankan oleh pendidik yang memiliki komitmen akan penghargaan terhadap keberagaman dan perlindungan terhadap perbedaan. Pendidik dengan komitmen seperti ini akan mampu membangun harapan sekaligus menciptakan lingkungan pembelajaran yang berpondasikan humanismes. Ia memposisikan dirinya sebagai fasilitator sekaligus pembelajar di waktu yang bersamaan.

Sementara dalam pandangan Lucas dan Villages, pendekatan ini bertujuan untuk mempromosikan nilai-nilai keberagamanan di dunia pendidikan. Lebih dari itu, CRT juga menjadi basis pemajuan ilmu pengetahuan dengan cara meningkatkan keterlibatan, pengayaan, dan pencapaian semua potensi keanekaragaman yang dimiliki setiap peserta didik. ${ }^{20}$ Kaitannya dengan proses pembelajaran agama Islam di kelas, guru dan komponen pendidikan yang menggunakan pendekatan CRT akan berupaya membenihkan pemikiran kepada peserta didik untuk melawan rasisme, xenophobia,

\footnotetext{
${ }^{19}$ Gloria Ladson-Billings. American Educational Research Journal, Vol. 32, No. 3. (Autumn, 1995 ) Republish 2005.

${ }^{20}$ Ana Maria Villegas \& Tamara Lucas. “The Culturally Responsive Teacher". In Educational Leadership (Module 6), (2002), hal: 1-7
} 
seksisme, prasangka, penindasan, intoleransi, dan ketidakadilan yang didasarkan keberagaman latarbelakang.

CRT sebagai sebuah pendekatan pembelajaran memposisikan pendidik bisa menjadi mediator yang salah satu tugasnya adalah menengahi ketidakadilan yang muncul di dalam kelas, yang diakibatkan oleh keragaman latar belakang tradisi, etnis, dan perbedaan lainnya pada diri setiap peserta didik. Peran mediator ini juga bekerja mengakomodasi kesenjangan dan merangkul berbagai respons budaya, bukan sebagai bagian yang terpisah, tetapi lebih sebagai bagian integral dari efektivitas proses pendidikan. $^{21}$

Sikap responsif dalam pendekatan CRT bukan sebatas menghargai kebudayaan lain, tetapi jauh dari itu sebagaimana dideskripsikan Guerra, guru yang menerapkan metode ini harus mengakui pentingnya identitas, bahasa, budaya, gender, dan perbedaan lainnya. ${ }^{22}$ Sementara itu, dalam membentuk cara siswa belajar dan menginformasikan pedagogi mesti ditumbuhkan sikap saling pengertian. ${ }^{23}$

Jadi, pada dasarnya, CRT bukan berhenti pada lontaran retorik yang hanya menyanjung keberagaman pada tingkatan formalis, karena idealnya metode yang progresif dan revolusioner, harus menyeimbangkan antara visi, harapan, dan praktik yang berkelanjutan, juga keseimbangan di antaranya harus dibumikan secara kritis. Menurut Villegas dan Lucas, seorang guru yang menerapkan metode ini harus memiliki 6 karakteristik, di antaranya: (a) memiliki kesadaran sosial-budaya; (b) memiliki sikap dan pemikiran yang berorientasi pada keberpihakan; (c) melihat orang lain sebagai agen perubahan dan pembebasan; (d) berupaya memahami bagaimana peserta didik membangun pengetahuan dan bagaimana mengomuniksikannya; (e) berusaha belajar tentang kehidupan peserta didik; (f) menggunakan pengetahuan untuk membangun apa yang sudah diketahui peserta didik sambil memperluas wawasan mereka untuk tidak hanya mengerti tapi juga memiliki pemikiran kritis, inovatif, dan responsive. ${ }^{24}$

Sekilas, penerapan pendekatan CRT sejalan dengan tesis Paolo Freire. Freire menekankan urgensi pendidikan sebagai proses pembebasan. Sebab dari aspek dialogis antara pendidik dan peserta didik, sama-sama menekankan interaksi di antara kedua

${ }^{21}$ Geneva Gay. Culturally Responsive Teaching: Theory, Research, and Practice (Multicultural Education Series). (3nd ed.) (New York: Teachers College, 2011), hal: 28.

${ }^{22}$ Juan C. Guerra. Language, Culture, Identity and Citizenship in College Classrooms and Communities. New York, NY: Routledge, 2016), hal: 86.

${ }^{23}$ James A. Banks. An Introduction to Multicultural Education. (4th ed.) (Boston, MA: Allyn and Bacon, 2008), hal: 47.

${ }^{24}$ Ana Maria Villegas \& Tamara Lucas. “The Culturally Responsive Teacher”....hal, 1-7 
pihak. Dialog kedua pihak ini sebagai proses penting dalam menguatkan mentransformasikan pengetahuan yang diterima peserta didik. Pada dasarnya, bagi Freire, pengetahuan tidak bisa "diwariskan" begitu saja, tetapi harus dibangun secara terus menerus melalui keseimbangan antara praktik dan teori yang reflektif dan dialogis. ${ }^{25}$

Dengan mendorong peserta didik untuk tidak berhenti hanya pada tahapan kemampuan memahami, tetapi mencapai pada tingkat kemampuan aktualitasi, internalisasi, dan re-interprestasi pengetahuan, maka implementasi pendekatan CRT dalam pembalajaran agama Islam akan membentuk karakter peserta didik yang terbuka terhadap keberagaman.

Sebab itu, di tengah peningkatan xenophobia dan rasisme saat ini, pendekatan pembelajaran berbasis CRT penting untuk diterapkan dalam setiap subjek pembelajaran, terutama dalam hal ini pembelajaran agama Islam yang semakin hari terjebak pada pemahaman yang ekslusif, fanatik, dan pembenaran sepihak. Ekslusivisme, fanatisme dan klaim kebenaran sepihak tidak hanya tertuju kepada rasisme dan xenophobia saat pandemi terjadi, tapi juga bagi kehidupan bermasyarakat, bernegara dan beragama di masa-masa yang akan datang. Sebab, belakangan ini, meuncul kecenderungan meningkatnya populisme agama, golongan, warna kulit, sentimen politik di berbagai belahan dunia. Prancis, Jerman, Amerika Serikat, Brazil dan banyak Negara besar lainnya.

Pada kasus di Indonesia, pasca Orde Baru jatuh (1998), berbagai tindak kekerasan yang mengatasnamakan agama, ras, suku, kelompok politik, hingga primordialisme kedaerahan muncul secara bertubi-tubi. Mulai dari konflik Muslim-Kristen di Ambon dan Halmahera (Maluku) dan Poso (Sulawesi Tengah) hingga kekerasan berbasiskan suku seperti Suku Dayak dan Madura di Sampit (Kalimantan Tengah). ${ }^{26}$ Bahkan, yang belum lama, Kathleen Azali, menyoroti maraknya persekusi berbaju agama di Indonesia mencapai 59 kasus yang terjadi sepanjang Januari-Juni 2017. ${ }^{27}$ Begitupun dengan Nafik Muthohirin menyebut berbagai aksi persekusi yang terjadi di Indonesia dalam beberapa tahun terakhir menggerogoti bangunan multikultural negara ini, sekaligus

${ }^{25}$ Paulo Freire. (2002). Pedagogy of the Oppressed. Print Book Edition: English. Rev., 30th Anniversary (New York: Continuum, 2002).

${ }^{26}$ Mengenai konflik agama di Ambon dan Halmahera baca selengkapnya dalam Chris Wilson. EthnoReligious Violence in Indonesia: From Soil to God (New York, Routledge, 2008).

${ }^{27}$ Baca dalam laporan riset yang dilakukan Kathleen Azali. "Fake News and Increased Persecution in Indonesia", PERSPECTIVE. Number, 16. Singapore, ISEAS-Yusof Ishak Institute (Agustus). 
menginterupsi peran damai yang dimainkan oleh ormas Islam seperti Muhammadiyah dan Nahdlatul Ulama (NU). ${ }^{28}$

Sejumlah organisasi keagamaan yang datang belakangan, seperti halnya FPI menjadi aktor yang menggerogoti bangunan multikultural di Indonesia, yang sekaligus menginterupsi kenyamanan ormas-ormas Islam mainstream layaknya Muhammadiyah dan Nahdlatul Ulama.

Pendekatan CRT untuk implementasi pembelajaran agama Islam penting dan relevan untuk menghadapi ancaman rasisme dan xenophobia yang belakang terjadi. Sebab jika tidak, berbagai kasus kekerasan berpotensi meledak dunia nyata yang pada akhirnya akan mengancam harmoni hidup umat beragama. Hal ini penting karena tujuan pendidikan Islam sendiri berinti pada penguatan agama yang tidak hanya berfokus pada atribut pribadi semata, tetapi secara inheren menjadi rahmat di ranah sosial dan budaya.

Dari titik penghormatan dan perlindungannya terhadap keberagaman inilah, CRT dan pendidikan agama Islam bertemu dan bisa saling bersinergi, apalagi ajaran Islam sangat responsif terhadap perbedaan budaya, bahkan Islam memandang perbedaan budaya dengan menyebutnya sebagai sunnatullah. Islam memandang perbedaan warna kulit, ras, agama dan kepercayaan adalah salah satu bukti kekuatan dan kebijaksanaan Allah Swt yang harus dijaga, bukan untuk dipertentangkan. ${ }^{29}$ Al-Quran juga menyerukan umat Islam untuk saling membantu, menyapa dan berbaur tanpa membedakan ras, warna kulit, dan budaya untuk menciptakan interaksi sosial yang berkeadilan dan menjunjung tinggi nilai-nilai perdamaian antara sesama manusia. ${ }^{30}$

Al-Quran memahami bahwa saling kenal (ta'aruf) bukan hanya sebatas kepentingan sesaat, apalagi digunakan untuk mencari perbedaaan, tetapi sebagai jembatan berkolaborasi dalam kebaikan. Ibnu Khaldun menjelaskan dalam magnum opusnya Mukaddimah, dijelaskan jika perbedaan agama, bahasa, ras, dan lain sebagainya adalah indikator peradaban sebuah bangsa yang perlu untuk dipupuk dengan harmoni. ${ }^{31}$

Namun, untuk menjadikan keberagaman sebagai modal utama memajukan sebuah peradaban, perlu dibangun kondisi saling pengertian (tafahum), saling bergotong royong dalam kebaikan (ta'awun), dan saling menjaga toleransi (tasammuh). Semua ini

${ }^{28}$ Mengenai maraknya persekusi dan bentuk politik identitas Islam yang berkaitan dengan pendidikan multikultural baca dalam Nafik Muthohirin. "Politik Identitas Islam dan Urgensi Pendidikan Multikultural". Jurnal Pendidikan Agama Islam (J-PAI) UIN Maulana Malik Ibrahim Malang. Vol. 6. No. 1 (2019), hal: 47-56.

${ }^{29}$ Baca Q.S. Ar-Rum: 22

${ }^{30}$ Baca Q.S. An-Nisaa: 58.

${ }^{31}$ Baca dalam Ibnu Khaldun. Mukadimmah (terj.) (Jakarta: Pustaka Al-Kautsar, 2011), hal: 89. 
diperlukan untuk perwujudan simbiosis budaya yang sehat yang bisa dimulai dari tingkat pendidikan, khususnya dalam hal ini adalah pendidikan agama Islam.

\section{Elaborasi sebagai Jalan}

Elaborasi antara pendekatan CRT dan pendidikan agama Islam bisa berfungsi sebagai teori juga sikap perlawanan terhadap berbagai aksi rasisme dan xenophobia. Sebab, komponen penting CRT mengakomodasi keragaman budaya, sehingga mampu menciptakan iklim kelas yang adil dan kondusif bagi peserta didik. Model ini dapat dilakukan dalam rangka membendung konstruksi sosial akan terjadinya rasisme dan xenophobia sejak dini. Dari aspek epistemologis, CRT menjadi pisau analisa untuk mengkaji kembali berbagai kesesatan berfikir dalam menerjemahkan teks agama.

Dari sudut pandang ini, pendapat Jurgen Habermas dalam the Theory of Communicative Action, Lifeworld and System: A Critique of Fungtionalist Reason menemukan relevansinya untuk melihat situasi sosial dan budaya yang terkoloni. Menurutnya, manusia di kehidupannya berada di antara dua ranah: Pertama, ranah komunikatif yang membuat horizon pandangan, nilai, wawasan, tradisi, hingga kebiasaan dalam berbahasa. Ranah ini pada akhirnya akan "mencetak bahasa" yang digunakan seseorang sehingga Muslim yang taat, pastilah dipengaruhi oleh wawasan keislaman yang tak tersadari hal ini terlihat ketika ia berpikir dan mengungkapkan pemikirannya melalui bahasa; Kedua, ranah sosio-kultural, di mana manusia hidup saling bertukar pikiran demi tercapainnya kesalingpahaman. Pada ranah kedua ini, Habermas membenturkannya dengan sistem yang menurutnya selalu mengoloni dunia kehidupan, sehingga "yang kultural" telah dikoloni oleh "yang institutusional" dan "yang publik" pada akhirnya dikoloni oleh "yang politik". 32 Pada saat terkoloni ini, manusia dijebak berbagai macam irrasionalitas, apalagi dalam hal beragama, yang akhirnya berdampak pada kesempitan berpikir ketika melihat fenomena sosial yang baru, dan belum ada dalam pengalaman beragama sebelumnya.

Pada aspek ontologis, pendekatan ini bisa menjadi wacana sanggahan dalam menghadapi berbagai narasi xenophobia dan rasisme. Umumnya, wacana sanggahan bersifat agitasi yang bisa berupa berbagai bentuk selama pola komunikasinya berlandaskan nilai-nilai Islam. Dalam hal ini, pola agitasi tidak diartikan secara negatif, karena pada dasarnya berada pada posisi yang netral dalam penggunaannya. Namun, yang perlu diketahui, dari sudut pandang positif, proses agitasi ini menujukkan kepedulian umat Islam pada permasalahan sosial yang sedang terjadi.

32 Jurgen Habermas. The Theory of Communicative Action, Lifeworld and System: A Critique of Fungtionalist Reason. (The 3 edition) (Boston: Beacon Press, 1990). 
Sementara itu, pada aspek aksiologis, elaborasi antara pendekatan CRT dan pendidikan agama Islam bisa menjadi langkah awal dalam membuat gerakan pendidikan agama yang profetik yang tidak hanya bicara kesalehan individual, tetapi juga bergerak untuk keadilan sosial dan kemashalatan bersama. Sebab itu, budaya kritis dan kesanggupan untuk merubah situasi ke arah yang lebih baik, dilakukan secara bersama antara seluruh stakeholder pendidikan dan peserta didik menjadi sangat penting diimplementasikan.

Pemahaman agama yang profetik menegaskan setiap individu untuk berbuat kebaikan sekecil apapun. Ia akan dengan sendirinya menjadi agen perubahan dan perdamaian di tengah-tengah kondisi yang tidak stabil akibat xenophobia dan rasisme. Sedangkan pemikiran kritis yang diagnostik dan kemampuan mengkomunikasikan wacana sanggahan akan menguatkan pemahaman peserta didik untuk mengenali akar persoalan dan memungkinkan mereka supaya tidak terjebak pada cara berfikir yang irasional.

Praksisnya, seorang guru yang mengelaborasi pendekatan CRT dengan pendidikan agama Islam harus berupaya secara bersama peserta didik meningkatkan kapasitas diri dengan membuat kerja-kerja bersama melalui proses dialog dan pelatihan kepemimpinan yang membaurkan semuanya tanpa mengenal latarbelakang perbedaan. Dalam hal ini, pelatihan kepimpinan yang dimaksud adalah berbasiskan nilai-nilai perdamaian dalam Islam.

Cara terbaik lainnya untuk mengatasi tantangan xenophobia dan rasisme juga adalah dengan mempromosikan literasi kebudayaan. Promosi ini perlu diinformasikan secara inklusif berbasis nilai-nilai keislaman. Dalam hal ini, peran dialog sangat penting baik antar guru dengan peserta didik maupun antara guru dan peserta didik dengan kelompok di luar kelas. Peserta didik perlu didorong agar membiasakan diri berdialog dengan teman-teman mereka, baik antar-etnis, antar-agama, maupun antar-peradaban agar tidak mudah tersulut fanatisme masing-masing primordialismenya ketika terjadai konflik yang melibatkan berbagai perbedaan yang dimiliki.

Dalam hal ini, dialog bukan hanya sarana untuk tujuan budaya yang bisa dibuang atau disisihkan begitu saja saat tujuan utama telah tercapai. Dialog kebudayaan perlu terus ditumbuhkan sebagai bagian dari literasi hidup. Budaya dialog perlu digunakan sebagai penangkal narasi kebencian yang berkembang pesat di banyak bagian dunia belakangan ini. Hal ini akan menjadi komponen integral dari literasi budaya yang ingin dihasilkan bersama. Sebab, dampak langsung dialog kebudayaan akan mereduksi kesenjangan dan ketidaktahuan yang terkadang bisa menjadi awal masuknya provokasi. 


\section{Penutup}

Keberagaman adalah sebuah keniscayaan yang tidak bisa diganggu dan digugat. Doktrin Islam mengajarkan bahwa Allah Swt menciptakan manusia supaya menjadi rahmat di tengah semesta ini. Sebab itu, bagian dari tanggungjawab sebagai khalifah fi alardl, maka nilai-nilai keislaman yang umat Islam yakini bersama salah satu aktualisasinya saat ini bisa ditunaikan untuk menolak berbagai aksi xenophobia dan rasisme. Kedua tindakan yang bernuansa kebencian tersebut merusak hak dan martabat orang lain. Melalui pendidikan agama Islam, strategi sistemik untuk menanmkan pemahaman penghargaan terhadap orang lain yang berbeda keyakinan, warna kulit, juga keragaman lainnya perlu dipupuk kepada peserta didik agar mereka berakhlak karimah.

Elaborasi CRT dan pendidikan agama Islam perlu dilakukan sebagai alat analisa, wacana sanggahan, dan jalan implementasi nilai-nilai Islam yang transformatif. Dengan begitu, pendidikan Islam akan menjadi batu penjuru untuk membangun generasi Islam yang berpandangan terbuka, toleran, dan berani menyuarakan Islam yang rahmatan lil alamin.

\section{Daftar Pustaka}

Ariely, Dan. (2016). Predictably Irrational: The Hidden Forces that Shape our Decisions. New York: Pinguin.

Azali, Kathleen. (2017). "Fake News and Increased Persecution in Indonesia", PERSPECTIVE. Number, 16. Singapore, ISEAS-Yusof Ishak Institute (Agustus).

Banks, J. A. (2008). An Introduction to Multicultural Education. (4th ed.). Boston, MA: Allyn and Bacon.

Essac, Farid (2012). Qur'an, Liberation and Pluralism: In Islamic Perspective of Interreligious Solidarity Against Oppression. Pinguin: New York.

(2009). On Being A Muslim: Finding a Religious Path in the World Today. London: Oneworld Publication.

Freire, Paulo. (2002). Pedagogy of the Oppressed, Continuum: New York.

Gay, G. (2011). Culturally Responsive Teaching: Theory, Research, and Practice. (3nd ed.), New York, NY: Teachers College.

Guerra, J. C. (2016). Language, Culture, Identity and Citizenship in College Classrooms and Communities. New York, NY: Routledge. 
Muthohirin, Nafik. (2019). "Politik Identitas Islam dan Urgensi Pendidikan Multikultural". Jurnal Pendidikan Agama Islam (J-PAI) UIN Maulana Malik Ibrahim Malang. Vol. 6. No. 1: Juli-Desember.

Villegas, A. M., \& Lucas, T. (2010). The Culturally Responsive Teacher Educational Leadership. 64 (6), 2833.New York. Pinguin publisher.

Wilson, Chris. (2008). Ethno-Religious Violence in Indonesia: From Soil to God. New York, Routledge. 